\title{
Louis Althusser on Politics and Processes of Filling Promotional Posts
}

\author{
Thulani Zengele \\ Victor Pitsoe \\ Department of Educational Leadership and Management \\ College of Education, University of South Africa, Republic of South Africa \\ tzengele@unisa.ac.za
}

\section{Doi:10.5901/mjss.2014.v5n2p333}

\begin{abstract}
Louis Althusser is no stranger to the politics of trade unions. Drawing heavily from Althusser's work, we critique the politics and processes of filling promotional posts in South African schools. We argue that the South African Democratic Teachers' Union (SADTU) fits the profile of a political Ideological State Apparatus (ISA) and has been enormously successful in securing ruling class hegemony in the education. While the function and structure of ideology is unchanging and present throughout history, our postulation is that, SADTU continues to make a major contribution to the ideological role of the State, and it "normalises" a massively hierarchical society. Notwithstanding the fact Althusser's theories were born of an attempt to defend what some saw as Communist orthodoxy, we find Althusser's work critical and relevant in critiquing the filling promotional posts.
\end{abstract}

Keywords: Ideological State Apparatus, ideology, SADTU, transactional leadership, promotional posts.

\section{Introduction and background}

One should first of all, perhaps, note that "how capitalism reproduces itself" can be very problematic. However, the reproduction of the relations of production is secured by the exercise of State power in the Repressive State Apparatus (RSA) and the Ideological State Apparatus (ISA). As Althusser (1971) writes, "the reproduction of labour power requires not only a reproduction of its skills, but also, at the same time, a reproduction of its submission to the rules of the established order, i.e. a reproduction of submission to the ruling ideology for the workers, and a reproduction of the ability to manipulate the ruling ideology correctly for the agents of exploitation and repression, so that they too will provide for the domination of the ruling class in words." Within this context, we argue that transactional leadership, as an ISA, is used subtly to ensure that there exists a reproduction of submission to the ruling ideology as well as a reproduction of the ability to manipulate the ruling ideology correctly for the agents of exploitation and repression. We depart on the assumption that the South African Democratic Teachers' Union (SADTU) fits the profile of a political ISA.

As Althusser (1971:112) puts it, "ideology has a material existence because an ideology always exists in an apparatus, and its practice, or practices. Ideology always manifests itself through actions, which are inserted into practices, for example, rituals, conventional behavior, and leadership and so on." It should be stressed that trade unions, as politicized subjects, are ideological state apparatuses (ISAs) - at the same time as ISAs they never declare themselves ideological. Among others, trade unions as ISAs, "exercise their members by the means of exclusion, selection etc; and they are one of the means by which workers are indoctrinated into modes of thought favourable to the continuation of capitalism (Althusser 1971)." While we recognise its good strides in the education transformation, for us, SADTU, through transactional leadership, perpetuates the reproduction of the relations of production by reference to aspects of ideological and political practice. The paper is organized into four sections. In the first section, we conceptualise Ideology and Ideological State Apparatuses. In the second section we sketch a critical analysis of filling promotional posts through Althusser's lens. Third, we examine Transactional leadership as ideological state apparatus. In the fourth section, we explore the perceptions on the filling of promotional posts emanating from the study conducted in the D12 District of the Gauteng Department of Education (GDE).

\section{Conceptualising Ideology and Ideological State Apparatuses}

It would seem apposite to begin this section by indicating that Althusser (1971: 143-4), a French Marxist philosopher, 
commonly referred to as a structural Marxist and a theorist of ideology, makes a distinction between what he calls the Repressive State Apparatuses (RSAs) (government, administration, army, police, courts, prisons) and the Ideological State Apparatuses (ISAs) (religion, education, family, law, politics, trade unions, communication, culture). For him, the ISA operate primarily through ideology - promoting the values and attitudes required by capitalism. Althusser says that an ideology always exists in an apparatus, and that while ideology in general has no history, specific ideologies have a history of their own. As Althusser (1970) observes, ideology is part and parcel of society itself; that is, ideology arises from the actual practices undertaken by institutions in society. As such, ideology forms the individual's consciousness and creates the person's subjective understanding of experience. Althusser (1970) writes that although the ISAs appear to be quite disparate, they are unified by subscribing to a common ideology in the service of the ruling class; indeed, the ruling class must maintain a degree of control over the ISAs in order to ensure the stability of the repressive state apparatus

Like Antonio Gramsci, an Italian writer, politician, political theorist, philosopher, sociologist, and linguist, Althusser turned to the realm of ideology. How people imagined their relationship to economy and society - the ideology that infused their actions - became his object of analysis. While Althusser compares "ideology" to Freud's "unconscious", his writing presents ideology in a similar way to Derrida's (a French philosopher) presentation of the language. Most importantly, his thesis states that ideology transforms individuals as subjects by a process of interpellation or hailing. He asserts that all "the subjects" from the moment of their births are already participants in the "material practices" of ideology. Althusser believed that the dominant beliefs, values and practices that constitute ideology serve a political function. The Government is for Althusser part of the RSA (Althusser, 1971: 143-4), and the Political ('the political system, including the different Parties') (ibid: 144 ) is decidedly an ISA.

Althusser (1971) demonstrates that "in order to exist, a social formation is required to essentially, continuously and perpetually reproduce the productive forces (labour-power), the conditions of production and the relations of production. The reproduction of productive forces is ensured by the wage system which pays a minimum amount to the workers so that they appear to work day after day, thereby limiting their vertical mobility. The reproduction of the conditions of production and the reproduction of the relations of production happens through the State Apparatuses (SA) which are insidious machinations controlled by the capitalist ruling ideology in the context of a class struggle to repress, exploit, extort and subjugate the ruled class". Althusser posits that it is not possible for a class to hold State power unless and until it exercises its hegemony (domination) over and in the ISA at the same time. Althusser's assertion is a more challenging proposition. He notes that "the reproduction of the relations of production is secured by the legal-political and ideological superstructure". For him, "it is secured by the exercise of state power in the SA and the ISAs. Furthermore, the role of the repressive SA consists essentially in securing by force the political conditions of the reproduction of relations of production which are in the last resort relations of exploitation. The SA also secures by repression the political conditions for the action of the ISAs."

To end this section, the South African Democratic Teachers' Union (SADTU) fits the profile of Political ISA. It is worth mentioning that Althusser's ideological state apparatuses work through material practices which interpolates individuals into subjects of ideology. Within this context, South African Democratic Teachers Union, as ISA, has been enormously successful in securing ruling class hegemony in the education. It continues to make a major contribution to the ideological role of the State, in that it 'normalises' a massively hierarchical society. The research by Letseka, Bantwini and King-McKenzie (2012) and Pattillo (2012) confirms that in union language doing well in education means carrying out the mandate of the union and not of the department of education.

\section{Critical Analysis of Filling Promotional Posts through Althusser's Lens}

It is plausibly best to start with the casual relationship between the filling promotional and Althusser's work. In doing so, we ground our philosophical account by illustrating, in brief, that the filling promotional posts through and implementation of teacher redeployment policies have a symbiotic relationship. To start with, Louis Althusser's work, Ideology and Ideological State Apparatuses (1971), is not alien in critiquing the ideology that is infused in politics and processes of filling promotional posts in South African schools. Althusser's work also offers nuanced understandings of the manifestations, functioning and effects of contemporary educational institutions and practices, more specifically in the of filling promotional posts. Within this context, we depart on the assumption that transformational leadership principles should inform and guide processes of filling promotional posts in South African schools - there is a theory practice divide. In contrast, SADTU, through transactional leadership, perpetuates the reproduction of the relations of production by reference to aspects of ideological and political practice. In essence, transactional leadership advocates that all subjects 
must reflect bureaucratic beliefs and values.

It is worth commenting on the aspect of hegemony as both a social and multi-layer construct. It is not our intention to dwell on the pendantics of trying to define hegemony, given a useful overabundance of literature on the subject already subsists. However, we content, though, that it is critical to have a shared understanding of what hegemony entails. Implicitly, hegemony is the dominance of the society's other classes in maintaining the socio-political status quo (Pitsoe, 2012). As so aptly put by Akita (2010), "hegemony, as a theory, has been used in virtually all spheres of human endeavour and in all kinds of relationships that suggest inequality. In addition, it is a constant struggle against a multitude of resistances to ideological domination, and any balance of forces that it achieves is always precarious, always in need of re-achievement. Gramsci's theory of hegemony has a totalistic quality in which everything is connected to everything else." In practice, the activities informing and guiding the filling of the promotional posts are largely dominated and characterised by a top-down approach; and perpetuate the capitalist hegemony. As Pitsoe and Letseka (2013:24) note, "in hegemony, the oppressed class literally "gives" the oppressors the permission to oppress them. Much of the hegemony occurs through social practices and beliefs which neither the oppressors nor the oppressed are aware of, thus the necessity for raising the consciousness of people as a prerequisite for true freedom."

Against this backdrop, Louis Althusser's thoughts offer a fairly neither truly structuralist nor poststructuralist account of the effects of the ideology that is infused in politics and processes of filling promotional posts. Section 8(2) of the EEA states that redeployment and filling of promotional posts may only be done with the approval of the School Governing Body (SGB) and subsequently endorsed by the Director-General of the Department of Education (DoE). The principal, also acting as the resource person, has to ascertain that redeployment and filling of promotional posts take place accordingly. The purpose is to ensure that teachers can work in an atmosphere that is free of nepotism and discrimination when promotional posts are filled.

Currently the teaching profession is becoming complicated, requiring the highest standards of professional practice to perform well under the guidance of effective school leaders. While this paper recognizes that the South African education system demands quality and new skills from the school managers, the process of identifying and redeploying, as a policy discourse, excess teachers in South African schools has been problematic as it is linked towards the filling of promotional posts. There is a striking notion that teachers who perform poorly in the classroom and are regularly absent from school due to union activities, get easily declared in excess and redeployed. In a study by Diko and Letseka (2009) on teacher attrition there are sufficient management aspiring teachers with Honours, Masters and even Doctoral degrees in educational leadership who get sidelined in favour of excess teachers when promotions are made.

Resolution 6 of 1998 and Section 3.6 of the EEA states that all teachers should be fairly treated during the redeployment process. The fact that teachers in excess, according to Resolution 6 , have to be given priority when promotional posts are filled leaves the Gauteng Department of Education (GDE) with no choice but to consider such teachers for promotion. Sayed (2002:29) refers to this as the "policy gap", that is understood as the mismatch between policy intention, practice and outcome since those targeted as in excess and undesirable within the teaching profession, end up promoted to management positions.

Albeit the critical roles played by teacher unions, more specifically the South African Democratic Teachers Union (SADTU), in the post-apartheid education transformation, their influence in teacher redeployment and filling promotional posts cannot be under estimated and taken for granted. Outstandingly, among others, the core values of democracy are not embedded in the current promotional posts. With devolution of management to the individual school site, this paper argues that the implementation of teacher redeployment policies and the filling of promotional post are riddled with corrupt practice and favouritism as argued by Letseka, Bantwini and McKenzie (2012) and Pattillo (2012). Both processes lack the democratic values and a substance of meritocracy.

\section{Transactional Leadership as Ideological State Apparatus}

Taking the reader through a vertiginous excursus in the history of the filling promotional posts through and implementation of teacher redeployment policy practice in the South African context, transactional leadership is an instrument of power, a social system to effect it (power), and a tool of political hegemony. With this in mind, this paper focuses on the notion of transactional leadership styles of management as espoused by the South African Department of Education (DoE). As Burns (1978) posits, transactional leadership involves an exchange of rewards for positive and supportive behaviour. Bass (1985) also suggests that there are two forms of transactional leadership behaviour, the contingent reward behaviour and the contingent punishment by others theories as cited in Mackenzie, Podsakoff and Rich (2001:117-118). The contingent reward behaviour theory is evident when followers have shown support for the 
leadership because they get rewarded. In this paper, the reward for loyalty to the union becomes the promotion which translates to power, recognition and higher salaries as Diko and Letseka (2009) assert that the applications of teachers for management positions are driven by the high salary packages rather than motivation to lead schools effectively.

The reward for loyalty to the union by its key members becomes punishment for suitably qualified and devoted educational leadership students that aspire to the same promotional posts. On the other hand, the contingent punishment behaviour theory by Bass (1985) becomes prevalent when promoted union followers do not fulfil the mandate of the union and get ostracised, intimidated and even forced to resign from their management positions when they do not fulfil the SADTU mandate as earlier cited by Letseka et al (2012) and Pattillo (2012). The Ntombela case that was earlier cited by Pattillo (ibid) and supported by Fleisch (2010) in his study on "The politics of the Governed" bears reference to the prevailing conditions at schools when there is an attempt to promote well qualified and deserving teachers against the wishes of the union leadership. This flies across the face of progressive educational reform principles aimed at ensuring that people get rewarded for good work that is performed when educating learners and providing an enabling environment for both learners and teachers.

Hoadely and Ward (2009) reveal that due to the significant role that parents play in School Governing Bodies (SGB), parents in mostly poor and township communities have little or no experience in school governance. This gives the teacher component of the SGB who are mostly SADTU members and union observers to manipulate the selection process in favour of their comrades thus sidelining suitably qualified applicants that are not affiliated to unions. Diko and Letseka (2009:232) reveal that sidelined teachers have stated that there is no reason why they should not resign from the DoE and look for employment elsewhere. Sayed (2002) in Hoadely and Ward (2009) contend that the circumstances within the SA education system call for a redress by all education stakeholders especially the government.

The research by Letseka, Bantwini and King-McKenzie (2012) and Pattillo (2012) confirms that in union language doing well in education means carrying out the mandate of the union and not of the department of education. In view of this statement we assert that getting registered and passing post graduate degrees and diplomas at university is not worth the while if the knowledge acquired in school management is not applied. The Ministerial review on school governance in 2004 resonates to the fact that there is a drive to transform school management by means of both decentralization and transactional leadership traits. We argue that such a process tends to benefit certain groups. In the SA context the dominant group that stands to benefit from decentralization is SADTU because of its alliance with the African National Congress (ANC) which is the ruling party in the South African government and the South African Communist Party (SACP).

Besides, SADTU has been instrumental in keeping the current government in power through the votes by teachers who form a significant section of the informed population. The transactional form of leadership that has transcended through the ranks within the DoE tends to benefit SADTU while compromising on values of good school governance that is based on commitment and the ability to implement educational policies effectively. The transactional leadership theoretical perspective becomes relevant for this study on the basis that the current trends in educational leadership seem to focus on loyalty to the union rather than to the needs of schools as will be argued during the discussion section of this study.

\section{General Perceptions on the Filling of Promotional Posts}

This section draws on Zengele's (2009) study, The Involvement of Teacher Unions in the Implementation of the Employment of Educators' Act 76 of 1998. It captures: (1) the perceptions of teachers on the filling of promotional posts; (2) the perceptions of principals on the filling of promotional posts; (3) The perceptions of the Labour Relations Officer (LRO) on the filling of promotional posts; (4) the perceptions of teachers on the filling of promotional posts

\subsection{The perceptions of teachers on the filling of promotional posts}

Teachers generally stated that unions fully participate instead of becoming observers in processes that involve the filling of promotional posts. One teacher mentioned this, "They only care about money and the fact that their member is in excess... so they will do anything to ensure that their comrades get more pay." Another one said, "If it is a post level one position you hardly see them, but come promotional posts they start being aggressive and intimidating." Another teacher said, "From post level 2 to 4 interviews they are there with a mandate from the union and if their member does not succeed there is a grievance". One teacher said, "To the detriment of the learner, nothing is really done to support learning. They (the unionists) would rather see to it that they are promoted." Another teacher added, "Instead of doing our 
work preparation we look for other posts advertised somewhere because we are not happy in this education department."

When asked why they complained because they were also union members, they answered that if you are not active enough in union activities like attending union conferences and workshops, you will not be considered and you will be sent to any school. When asked about the role of the SGB's, they said, "There is no fairness, unions influence uneducated parents, and if the SGB is strong you see a lot of grievances." One of the teachers said, "Education is going down the drain". Another one asserted, "They push you up so that once you are up, you look after those who are behind. So, there is no way of successfully reporting nepotism when the authorities themselves have been deployed by their union".

Almost all teachers mentioned that promotional posts were filled according to the applicants' participation in union activities. The unions decide well in advance on who will be appointed to post level 2 which is the departmental head, post level 3 which is the deputy principalship and post level 4 which is the principalship as they have a list of teachers in excess. One teacher said, "They caucus, I can't say it clearly because I am afraid, it depends on who are you. Who do you know? Otherwise you must make yourself known." Through their involvement the panel tends to look at union affiliation rather than the needs of the school when there is a union member in excess. Teachers indicated that he process became worse when the principal was also a unionist.

Another teacher expressed her concerns in this way, "We have Sadtu occupying all the senior positions within the DoE. You know Sir, they come with their lists of who will be appointed at which school, and they call this the deployment of their own members to key positions, just like it happens in politics. All the political parties submit party lists for those who will be in parliament. Those who don't get onto the ANC lists jump over to COPE and the same applies in schools. You know, I always feel like leaving this department because I work hard but there is no reward." (COPE refers to the Congress of the People Party which was the breakaway faction formed in 2008 by the disgruntled members of the ANC after the Polokwane ANC conference in December 2007). Teachers told the story of another experienced and highly qualified teacher who had acted as a deputy principal for nearly a year but was not appointed because the union dominated interviews and short-listing. They said, "This teacher feels used and dumped. We now have a poorly qualified and less experienced deputy principal just because she is connected to the union". The following section reports on findings from the interview with school principals.

\subsection{The perceptions of principals on the filling of promotional posts}

The principals agreed that the unions attended the short-listing and interviewing process as observers, but things changed when their member was in excess and not recommended because there was a dispute lodged at the district office. When asked about the steps taken to fill promotional posts, one principal said, "Sir, as usual they look after the interests of their members. If the employer is weak, they push their agenda and they win. They look for their member and say, this one is the correct candidate" The same principal concluded by saying, "That's why, today, we don't have quality teachers and managers in our schools." These views were also shared by the teachers, as reported in the previous section.

Regarding nepotism, another principal, as earlier mentioned by teachers said, "You know what happens in politics, for instance there is COPE now, because the ANC did not give jobs to certain members." The principal continued, "You know, sir, in the olden days for a person to become a departmental head you had to prove yourself in the classroom, and to become a deputy principal you had to become a good departmental head, and lastly, to become a principal you had to become a good deputy principal. So, today you find a post level 1 classroom teacher getting promoted straight to the principalship simply by virtue of being an active union member on the excess list. Unions do not consider the quality of their members in the classroom. In my experience, teachers get involved in unions in order to get promotions and protection once they are declared in excess."

The principals interviewed showed displeasure at the way teachers were appointed to promotional posts. They stated that what made matters worse was that qualifications were not considered when they recommended their members. One said, "As long as you have a certificate and you are a union key member you will get the promotion." There was also a degree of resentment among principals concerning the dropped performance rate among learners. One of them asked, "What happened with the results in 2012? They are coming down because the Department of Education has lost its grip". The following section reports on the interview with the Labour Relations Officer (LRO). 


\subsection{The perceptions of the Labour Relations Officer (LRO) on the filling of promotional posts}

The LRO responded in this manner"...the modus operandi for various unions differs, for example, some unions go according to the letter of the law". She further continued to say that "...some unions violate the rules by placing friends for positions long before they are advertised. For instance, they know that a principal is about to retire. Strategically they have someone reserved for that position. In so doing, they do not consider the curriculum and leadership needs of the institution. They want to influence the SGB by bringing their lists of people to take over the positions." The LRO put it in this manner, "They bring their lists; it's like political lists. They go to short-listing meetings and intimidate the SGB panel by threatening to lodge a grievance should their member be unsuccessful. The bigger union (SADTU) is always guilty of this. The bigger union also has a vast membership of younger educators who have little respect for authority."

The LRO explained that the trend amongst younger teachers was to look after their own interests rather than those of learners. She, however, indicated that there were isolated cases where young teachers were properly placed in positions. In her own words she remarked, "generally speaking, the union deploys members to schools rather than helping them to be employed." The LRO indicated that there was little that could be done to resolve the situation because the senior employees of the GDE were also well-known unionists. In the LRO's own words, "What do you do when the employer is also in the same organization? You are helpless in this kind of situation." The LRO even declared atrociously that she was not free to be interviewed in this respect because some of her senior colleagues at District and Head office have been appointed on, what is referred to as, "...the SADTU ticket."

In the light of the above, the transactional style of leadership is evidently prevalent within both the leadership hierarchy of the DoE and that of SADTU. As Burns (1978) writes, "transactional leadership involves an exchange of rewards for positive and supportive behaviour." The LRO does support SADTU when acceding that sometimes the process goes peacefully when there is no opposition. The non-existence of opposition to SADTU expectations does not mean that such expectations are always legitimate as it could be the fear that unaffiliated teachers and DoE officials experience when SADTU becomes part of the process. Resolution 6 of 1998 and the EEA dictate that all unions should maintain the observer status during selection processes. Research by Diko and Letseka (2009), Fleisch (2010); and Pattillo (2012) support the LRO and teachers' statements that there is indeed intimidation going on in schools during the selection process. Fleisch (2010) even goes on to say SADTU is prepared to use even physical violence when other stakeholders do not conform to their demands to have their key members promoted. The same sentiment is echoed by Pattillo (2012) when referring to the Ntombela case whose office furniture and car were savagely vandalized by SADTU when he refused to honour the similar SADTU mandate.

The LRO claims that the state of education in SA is compromised through the infiltration of senior positions by poorly prepared mostly SADTU managers within the DoE. Reference is made by Zengele (2009) when alluding to the appointment of the past SADTU Presidents, Mdladlana who became a minister of labour and Hindle who became the Chief Director and later a Director -General of Education of South Africa and the list is endless. What drives the union's choice for candidates to be promoted seems to be loyalty to SADTU rather than the professional qualifications of applicants and this seems to peeve dedicated teachers.. In this case the implication is that no effective teaching goes on in schools until an identified SADTU member has been appointed to the SADTU identified position. Bass (1985) as referred to earlier in this paper suggests that there are two forms of transactional leadership theories, the contingent reward behaviour and contingent punishment by others as cited by Mackenzie, Podsakoff and Rich (2001:117-118). Findings show that the Bass (1985) contingent reward behaviour theory is evident when mere loyalty to SADTU becomes basis for promotion as espoused by Letseka et al (2012). Pattillo (2012); Fleisch (2010); Fleisch and Christie (2011) posit that SADTU affiliated teachers spend less time in the classroom in favour of union meetings that often take place during teaching time as confirmed during the interviews with teachers.

We recognize that the SADTU invasion of the selection process as active members instead of participation as observers happens due the ill preparedness by SGB's because of the low educational levels of parents who form the majority SGB component in poor communities. It is a well-known fact in SA that the majority of teachers belong to SADTU because of its history of having fought the SA apartheid regime in the past (Zengele, 2009:1). At the same time the LRO posits that it is difficult to report SADTU members because the senior managers of the DoE are also there on the "SADTU TICKET" and this is the term that was used verbatim by the LRO during the interview. Recent research by Letseka et al (2012) and Pattillo (2012) confirms that in union language doing well in education means carrying out the mandate of the union and not of the department of education since teachers clearly articulated during the interviews.

The DoE has the mandate to ensure that well qualified school managers are appointed for schools to function effectively. The compromised state by the DoE since 1994 makes it difficult to carry out its mandate and this seems to be 
the reason various researchers like Fleisch and Christie (2004); Bloch (2009) and Fleisch (2010:), state that education in South Africa is in tatters and in a state of collapse. In the author's view the reason the DoE is in such a compromised state is that the senior DoE management including the current Minister of Education are mostly SADTU deployees. They also know the consequences of not carrying out the SADTU mandate as Pattillo (2012) refers to the earlier cited Ntombela case in her study on "Quiet corruption" and in line with the contingent punishment by others theory as espoused by Bass (1985).

Common findings during all the interviews reveal that all the participants are aware of the enormous power that SADTU yields across the DoE because of its affiliation to COSATU which is in a tripartite alliance with the SACP and the ANC, the ruling party in Parliament. All stakeholders that were interviewed also share doubt that there is an imminent solution because of the DoE concessions with SADTU since 1994 regarding the allocation of senior positions to SADTU key members as a "thank you " for supporting the present government to be in place.. In the study by Fleisch (2010) and Letseka et.al (2012) it is stated that it has become easy for SADTU to disrupt schooling if their mandate is not carried out. The same researchers also argue that the officials that have to take disciplinary action against them are SADTU deployed officials as well who are thus unable to discipline their members for fear of reprisals already mentioned. This is synonymous to Greece and the USA as Letseka et al (2012) relate to events leading to the resignations of four Education Ministers in Greece for supporting performance related pay principles for teachers. The interview with the LRO reveals and confirms the compromised state of the DoE because of patronage-based appointments within the DoE when she labels such promotions as the "SADTU TICKET".

\section{Conclusion}

While we recognise its good strides in the education transformation, this paper argued that, SADTU as politicized subject, through transactional leadership, perpetuates the reproduction of the relations of production by reference to aspects of ideological and political practice. From a capitalist stance, it fits the profile of political ISA. We also argued SADTU that has been enormously successful in securing successful in securing capitalist hegemony in the education, and continues to make a major contribution to the ideological role of the State, in that it 'normalises' a massively hierarchical society. To end this section, we perceive transactional leadership as an instrument of power, a social system to effect it (power), and a tool of political hegemony.

\section{References}

Akita EM 2010) Hegemony, Patriarchy and Human Rights: The Representation of Ghanaian Women in Politics. Published Dcotoral Thesis. College of Education of Ohio University.

Althusser, L. 1971. Ideology and Ideological State Apparatuses: Lenin and Philosophy, and Other Essays (pp.127-188). Trans. Ben Brewster. London: New Left Books

Babbie, E. 2010. The Practice of Social Research. Twelfth Edition. USA: Wadsworth.

Bass, B.M. 1985. Leadership and performance beyond expectations. New York: Free Press.

Bloch, G. 2009. The toxic mix: Whats wrong with SA's schools and how to fix it. Cape Town: Tafelberg Publishers.

Burns, J.M. 1978. Leadership. New York: Harper \& Row.

Denscombe, M. 2007. The Good Research Guide for Small-scale Research Projects. 3rd Ed. England: McGraw-Hill.

Diko, N N, Letseka M 2009. Policy appropriation in teacher retention and attrition: the case of North-West Province. Perspectives in Education, 228-236.

Fleisch, B. 2010. The Politics of the governed: South African Democratic Teachers' Union Soweto strike. June 2009. South African Review of Education, 16: 117-131.

Fleisch, B. Christie, P. 2004. Structural Change, Leadership and School Effectiveness/Improvement: Perspectives from South Africa. Discourse: studies in the cultural politics of education, 25(1): 95-112

Henning, H., Van Rensburg, W. \& Smit, B. 2004. Finding your Way in Qualitative Research. Pretoria: Van Schaik.

Krueger, R.A. 1988. Focus Groups. Newbury Park. CA: Sage.

Letseka, M., Bantwini, B., and King-McKenzie, E. 2012. Public-Union Sector Politics and the Crisis of Education in South Africa. Creative Education, I3(7): 1197-1204.

Lewis, M. 2000. Focus Group Interviews in Qualitative Research: A Review of the Literature. Action Research E-Reports, 2. Available at www.usyd.edu.au/arow/arer/2002.htm

Mackenzie, S.B., Podsakoff, P.M., Rich, G.A. 2001. Transformational and Transactional Leadership and Salesperson Performance. Journal of the Academy of Marketing Science. 29(2): 115-134.

Measor, L. 1985. Interviewing: A Strategy in Qualitative Research. In: Strategies of Educational Research: Qualitative Methods, ed. R.G Burgess. London: Falmer. 
Moe, T. 2011. Special interest: Teachers Unions and America's Public Schools. Washington DC Brookings Press.

Pattillo, K.M.C. 2012. Quiet Corruption: Teachers' Unions and Leadership in South African Township Schools. Thesis submitted to the Wesleyan University. Middletown, Connecticut.

Pitsoe, V. 2012. Teaching Human Rights Education: A Foucauldian Discourse Journal of Sociology Social Anthropology, 3(2): 153-161.

Pitsoe, V. and Letseka, M. 2013. Foucault's Discourse and Power: Implications for Instructionist Classroom Management Open Journal of Philosophy, 3(1): 23-28.

Rossman, G.B. 2003. Learning in the field: An introduction to qualitative research. Thousand Oaks, CA: Sage.

Taylor, N. 2008. "Whats wrong with South African schools?" A Five Year Plan for South African Schooling. A Report Commissioned by the National Planning Commission. JET Education Services. Pretoria: Government Press.

The Economist. 2011. Briefing: Public-sector workers. The Economist: January 8-14.

Van Onsellen, G. 2012. South African Political Dictionary: Cadre employment and cadre deployment at www.inside-politics.org (retrieved November 30, 2012)

Weber, M. 1958. The Protestant Ethic and the Spirit of Capitalism. Translated by Talcott Parsons. New York: Scribner.

Zengele, V.T. 2009. The Involvement of Teacher Unions in the Implementation of the Employment of Educators' Act 76 of 1998. D.Ed. Thesis (Published), Pretoria: University of South Africa. 